\title{
THE QUALITY ASPECT OF MANAGEMENT IN THE CONSTRUCTION SECTOR
}

\begin{abstract}
The article deals with issues connected with the construction activity in Poland and the EU. The socio-economic development of countries depends on investment activities. Because of this, the construction sector which can attract investments, is widely regarded as one of the fundamental pillars of the economy. The growing demands for high quality construction products - with particular emphasis on their aesthetic and quality, as well as the dynamic technological progress - contribute to the increase in the complexity of the construction activities. This is visible among others in the area of organization and technology. The companies that are worried about the quality of their products and wishing to get a suitable place on the market are trying to get the appropriate marks and certificates confirming it.
\end{abstract}

Keywords: construction activity, quality, safety marks, quality mark, quality control system

\section{Introduction}

Construction and building engineering create an area of human activity related to the building creation, reconstruction, modernization, and preservation of existing facilities. It deals also with the demolition of buildings that do not meet the technical requirements (e.g. for safety) or for other reasons, must be removed from the occupied plots - e.g. because of the construction of another facility on the same site. The construction sector (industry) is composed among others of civil, commercial, residential, and environmental construction (BOLKOWSKA 2008).

Building engineering is a branch of practical knowledge as well, that contains the techniques used in building area.

In the era of globalization, when customers can purchase products and services in any country of their choice, management of a company in order to be efficient and act effectively requires the use of information technology and the Internet. Broadly speaking, the construction activity includes an area of the economy characterized by the high volatility and uniqueness of tasks and processes. The complexity of modern structures requires also a great deal of creativity and flexibility. This is due to the fact that in the practice one must cope often with the different building structures. As an

${ }^{1} \mathrm{PhD}$., Czestochowa University of Technology, Faculty of Management, Department of Production Engineering and Safety, e-mail: asros@op.pl

${ }^{2}$ Student, Czestochowa University of Technology 
additional factor, the external conditions of each construction project are (KOWALSKI D. 2013, Witakowski P., Grauman R., BernasiK J., Mikrut S., KWIATKOWSKi W., MAZUREK G., KOZARZEWSKI M., UHL T., HANC A. 2010):

- execution time;

- budget of the project;

- environmental conditions during construction;

- access to technology.

The final factor in the great variety of circumstances present in a construction project, is the potential of engineering and technical staff and manual employees performing various tasks related to construction. Poland is the leader of growth in the construction industry. This is the case both among the new EU countries, as well as throughout the European Union. This country was able to achieve an increase in the value of the construction output of 30,4\% in 2011 more than in 2010.

\section{Construction activity in Poland and in the World}

Studies carried out by the Polish Agency for Construction Research (Polska Agencja Badawcza Budownictwa) indicate that between the years 2001-2003 there was a regress in the European construction sector, which reflected in economic stagnation in the EU countries. This was the case also in Poland. This country has a relatively small share in the construction market of the EU - its participation in the European construction output was estimated at $2 \%$ in 2003. Despite the weakening pace of development of construction in the recent years, Germany was and still is the largest construction market in Europe.

The ratio of the output of the construction industry in Poland referred to the GDP in 2003 amounted to $9.9 \%$ and was $0.4 \%$ points lower than in other EU countries, and it was $6-8 \%$ points lower than in the EU countries that were admitted to the community in the eighties (Spain, Portugal and Ireland ). It would be important to point out that these countries were quickly reducing the gap between them and the more developed "old EU member states".

The value of the Polish construction market, estimated in 2003 at approx. 21.5 billion, meant that Poland ranked together with Ireland in tenth and eleventh place ahead of Finland, Denmark, Sweden and Greece, and the group of nine European countries that acceded the EU in 2004 - the same year that Poland joined (WIŚNIEWSKA K. 2005, SOCHACKI A. 2012, SOCHACKI M. 2004, SOCHACKI M. 2001).

\section{Modern management in the construction industry}

Modernization of the construction industry means above all, a new approach to the quality issue. In this context, the development of quality systems must be taken into 
consideration. The improvement of these systems allows to achieve higher quality in every area of production. The importance of these systems in the construction industry differs, however, according to the specifics from the other sectors of industry. Construction law plays a significant role in this case. The quality system in the construction area generally contains measures, the use of which ensure high efficiency of the work and good quality of the end-products.

There are many construction companies in Poland that didn`t use the modern form of technological support in the past. This situation has changed nowadays. Today, the developers already know that they should increase the involvement of the new tools in their work. They are aware that this can be key to their business success. The lack of informatics techniques such as CRM and Workflow can, however, be very dangerous. Hence the conviction of the need to use modern information technologies (BIRUK S., JASKOWSKi P. SOBOTKA A. 2003, PABIAN A. 1999, CIESZYŃSKI K. 2006).

There are following quality systems (GRÓCA-WOJTOWICZ P. 2009):

1. Quality control systems (QCS). Systems of this level have been known for a long time. Their action is based on the functioning of quality control of finished products and the proof of them according to a certain quality criteria. If the product does not meet the requirements, it is eliminated from further rotation. Until recently, the symbol of the quality control systems were departments of quality control and sorters.

2. Quality assurance systems (QAS). These systems are based on ISO (International Standard Organization) standards since 1994. They include a process of checking to prove whether a product being developed is meeting the requirements. A characteristic feature of these systems is to act on the basis of quality assurance procedures. These procedures define precisely all the components of the manufacturing process and the conditions under which these actions should take place to obtain products of good quality. In contrast to the systems of quality control, the essence of quality assurance systems is the elimination of the danger that the products do not meet quality criteria.

3. Quality management systems (QMS). These systems are also based on ISO standards. A characteristic of these systems is that they include the "total" control of all production processes. They are based on a division of the processes into subprocesses. This affects the quality of the end product. Unlike the quality assurance systems - these systems have not the purpose to follow faithful established procedures - but to achieve improvement of the quality of the work through continuous data analysis of the processes. The QMS systems also enable the continuous improvement of processes by the implementation of the latest 
achievements from the area of technique and organization. These kinds of systems make possible a comprehensive optimization of the producing process.

4. Systems of total quality management TQM (Total Quality Management). These quality management systems focus on covering all the processes operating in the production and enabling comprehensive optimization of the production. The processes mentioned above are not treated separately but as a whole. A dynamic process of moving from the lower to the higher levels of quality management systems is clearly noticeable.

Because of the fierce competition on the construction market, having a quality mark is necessary. According to this having a quality mark - like a certificate ISO 2000 - is a universally recognized standard among the major construction companies.

Due to the significant competition in the EU and the lack of barriers in the form of borders, businesses that do not have this certificate cannot cope with the competition, and in practice cannot survive in the market. No construction company has managed so far, however, to implement the whole TQM system. Noticeable is also the correlation between the level of the quality system and the computerization of the institution; one can say the higher the level of the quality system, the greater the demand for information systems.

\section{Modern management in terms of safety and quality marks}

The two basic documents which are in force in Poland are: Polish Standard and Polish Technical Approvals. These documents define the characteristics of products and construction materials. They determine what should be the construction product and for what specific purpose it is made. The Polish Committee for Standardization coordinates and updates Polish Building Standards.

After undergoing construction materials attestation according to the requirements of the Polish Building Standards and Technical Approvals, construction materials receive Building Mark B. The Building B Mark - the national mark is applied to the construction products (Buildings Directive 89/106 / EEC) in the absence of a harmonized standard or the European Technical Approval (ETA).

At the time of Polish accession to the European Union, the Polish domestic market became a part of the large EU united market. This meant for Poland the privilege of the free movement of goods. There are no customs barriers and no border controls anymore. The goods, without major obstacles, are transported from the country where the product was manufactured to the country of sale. This can lead to the situation in which the consumers of the country of destination may have problems recognizing the product indications of the Building Standards in force in the country of origin. This problem has become an inspiration for the introduction of the $\mathrm{CE}$ marking. $\mathrm{CE}$ 
mark derives etymologically from the French term Conformité Européenne (which means European Conformity), it is called by some institutions in the EU as the "EU passport", which allows the manufacturers to introduce their products to the markets of all the Member States of the European Union and countries associated with this institution in the so-called European Economic Area (this mean Well as Norway, Iceland and Liechtenstein).

According to directives of the New Approach, the CE marking is required in products such as:

- active medical implants,

- cranes,

- devices emitting noise in the environment by equipment intended for use outside rooms,

- yachts,

- devices with electromagnetic compatibility,

- machines,

- explosives for civil use,

- non-automatic binding devices,

- low voltage electrical products,

- simple pressure vessels,

- the energy efficiency of refrigerators and freezers,

- energy efficiency of water boilers,

- energy efficiency stabilizers for fluorescent lighting,

- personal protective equipment,

- equipment for use in explosive atmospheres,

- pressure equipment,

- gas appliances,

- medical devices,

- in vitro diagnostic devices,

- unit cars for the transport of persons,

- radio equipment and telecommunications terminal equipment,

- construction products,

- toys.

The Highest Quality Mark in Construction awarded to companies, public organizations, local governments and individuals, who through their work contribute to raising the quality of life and to creating the guarantee of the highest quality of services in terms like (http://cerbud.org.pl):

- investment performance,

- construction work, 
- counseling,

- design,

- montage;

- general construction,

- industrial construction,

- residential construction,

- public utility,

- adaptation,

- repairing,

- and the revitalization of historic buildings and churches.

The certificate is awarded on an annual basis since 2004 .

The Quality Mark "Good Concrete" was established by the Concrete Association (SPBT). This mark was established in order to (http://gwarantowanystyropian.pl/wp-content/uploads/2015/05/LISTA-20141.pdf):

- integrate the environment,

- inspire the development of Polish standardization, certification and legislation in the field of concrete,

- promote the development of factory quality control,

- improve the manufacturing level by identifying leaders Mark Good Quality Concrete,

- create a platform for the exchange of experiences between members,

- take care of the natural environment where the concrete plants are build, as well as the supply and application,

- assist in adapting EU regulations to national specificities,

- inform about the expectations of the EU structures to manufacturers of concrete,

- cooperate with related foreign organizations,

- help customers to make contact with a professional concrete manufacturer capable of producing concrete in compliance with the European quality standards.

The Quality Mark of Concrete was established by the Concrete Association (SPBT). It was brought to life in order to:

- integrate the environment;

- inspire the development of the Polish standardization, certification and legislation in the field of concrete;

- promote the development of factory quality control;

- improve the manufacturing level by identifying good managers (leaders) and honor them with the Mark Good Quality Concrete;

- create a platform for the exchange of experiences between members; 
- take care of the natural environment surrounded by concrete factories, the supply and application;

- assist in adapting EU regulations to national specificities;

- inform about the expectations of EU structures to manufacturers of the concrete;

- cooperate with related foreign organizations;

- facilitate customer contact with the professional concrete producers, capable to produce concrete in compliance with the European standards.

The Quality Mark of Concrete was founded as a reaction of SPBT to irregularities and difficulties accompanying manufacturing and distribution of concrete in Poland - primarily the overlooking of the innovative solutions connected with the European standard EN 206-1 - both by building designers, and buyers mix of construction. Another problem is that the existing law discriminates concrete as a construction product. The market is often treated as a platform for unfair competition from the "gray" economy. The specified producer groups do not keep technological standards - e.g. their products are of poor quality, the chemical composition of the products is wrong or the weight of the load is underestimated. As a result, a portion of the clients suffer loses - they are helpless about the practices mentioned above. In Poland, there are currently 73 firms that are members of the Association SPBT. The Quality Mark of Concrete is a confirmation to the customers that they:

- have an efficient, modern organization of production, managed by autonomous computer that controls, among others, official weights of ingredients and the apportionment of loading,

- have the support of competent staff, laboratory services and technology,

- make use of qualified raw materials,

- have an implemented system of factory production control according to European standard EN 206,

- are able to produce and provide for the construction of concrete properties that comply according to the order and the requirements of Polish standards,

- provide guarantees for their products,

- if necessary - can send to the construction site their own service technology, and provide advice in the field of the concrete work,

- produce concrete without questioning the quality by the outsides, or at a very low threshold of the complaint,

- protect the environment and respect the rules of sustainable development.

The Polish's Brick Mark has been appointed by the National Association of Producers of Construction Materials CERBUD in order to offer consumers and users of building ceramic construction materials with high, proven quality, produced from 
verified and reliable manufacturers. There are currently 50 manufacturers that have the Polish's Brick Mark.

The Guaranteed Quality Mark "Styrofoam" (RENEV I.A., CHECHURIN L.S. 2016) was initiated by the Polish Polystyrene Producers Association (PSPS) in 2010 with the purpose of maintaining quality of products from polystyrene that are used for construction services on the Polish market - and in consequence - to achieve the safety and comfort of buildings (RYTEL O. 2009, UBREZIOVA I, HORSKA E. 2013).

The most important goals of the Guaranteed Quality Mark "Styrofoam" are to:

- promote knowledge about the products from polystyrene,

- harmonize rules of the clear and unmistakable labeling of products,

- certificate honest and reliable producers,

- promote high quality products,

- eliminate the phenomenon of offering customers badly labeled products.

Currently, 26 companies in Poland use additional marking of products.

The Eagles of the Polish Construction Mark is granted to construction companies which make buildings both modern and safe, and create an added value for the Polish construction market. Obtaining the Eagles of the Polish Construction Mark gives important privileges:

- means prestige and arouse confidence in the eyes of the business partners,

- help in acquiring new customers and investors,

- confirms innovation in management,

- increase the company's possibilities.

- help to take the proper position in the market,

- allows to strengthen the company's position in the market.

\section{Summary}

The analysis of the situation in the construction industry shows the great importance of the chemistry products area of this sector. The quality of these products depends to a large degree on the raw materials used in their production. Because of this, maintaining high quality standards is particularly important. This can be achieved through standardization, quality certifications, and the use of the appropriate logistics infrastructure.

The main factor which helps to stimulate the economic situation in the construction business is the acceleration of economic development ${ }^{3}$. Companies that

\footnotetext{
${ }^{3}$ M. Sochacki, Ospały wzrost w budownictwie europejskim do 2007 roku, Rynek Budowlany, nr 391, $3 / 2005$.
} 
want to achieve lasting success in the market usually want to compete on the quality of services or goods.

The construction sector is strongly associated with many different areas of the economy, and at the same time heavily dependent on them. Without the building activities of production, neither provision of broadly defined services, nor meeting the individual and collective consumption needs of citizens are possible. Construction activities lead to economic recovery, activate the many branches of the economy and mobilize the society for creative activity. The construction sector impacts heavily the labor market - in the case of the recession or lower intensity of work - the unemployment increases; in the case of prosperity and high intensity of work - the employment increases - even the low-skilled ones. However, it is worth mentioning in this context that there is no ready-made solutions or standard models of conduct to guarantee each company success and durable competitive advantage (DoBIEGAŁAKorona B., KASIEWICZ S. 2000, SKORUPKA D. 2008).

\section{Bibliography}

1. BIRUK S., JASKOWSKI P. SOBOTKA A. 2003. Zarzadzanie w budownictwie: Organizacje, procesy, metody. Wydawnictwo Politechniki Lubelskiej, Lublin.

2. BOLKOWSKA (RED.). 2008. Budownictwo polskie w latach 1990-2007. Przeglad retrospektywny, szanse rozwoju $i$ ograniczenia wzrostu. Wyższa Szkoła Zarządzania i Prawa w Warszawie, Warszawa.

3. CIESZYŃSKI K. 2006. Zarządzanie $w$ budownictwie. Fundacja Edukacji Menedżerskiej Budowlanych, Warszawa.

4. DobIEgAlA-KoronA B., KASIEWICZ S. 2000. Metody oceny konkurencyjności przedsiębiorstw, w: Uwarunkowania konkurencyjności przedsiębiorstw w Polsce, red. K. Kuciński, „Materiały i Prace IFGN”, t. LXXIX, Oficyna Wydawnicza SGH.

5. GrócA-Wojtowicz P. 2009. Systemy jakości $i$ bezpieczeństwa $w$ jednostce sektora ochrony zdrowia, ,, Problemy Jakości”, nr 8.

6. JANIK R., The Ecological and Social Costs of Economic Development and Their Influence on Management in Europe. (In:) Universal Journal of Management, Vol. 3(10), DOI: 10.13189/ujm.2015.031001

7. KOWALSKI D. 2013. Zapewnienie jakości robót i materiatów $w$ realizacjach budowlanych. Inżynieria morska i geotechnika, 5.

8. PABIAN A. 1999. Marketing w budownictwie: poradnik przedsiębiorcy budowlanego. Centralny Ośrodek Informacji Budownictwa, Warszawa 1999. 
9. Renev I.A., CHEChURIN L.S. 2016. Application of TRIZ in Building Industry: Study of Current Situation, Procedia CIRP, Volume 39, pp. 209-215, Structured Innovation with TRIZ in Science and Industry: Creating Value for Customers and Society.

10. RYTEL O. 2009. Specyfika produkcji budowlanej. Zeszyty Naukowe Akademii Podlaskiej w Siedlcach, Nr 83.

11. SKORUPKA D. 2008. Zarządzanie Ryzykiem w Przedsięwzięciach Budowlanych. Zeszyty Naukowe WSOWL, Nr 3 (149).

12. SOCHACKI A. 2012. Niespetnione oczekiwania na poprawe w europejskim budownictwie w 2011 roku. Materiały Budowlane, nr 475, 3.

13. SoCHACKI M. 2001. Wielkość i struktura budownictwa przemystowego w Polsce. Budownictwo przemysłowe, nr 510, 2.

14. Sochacki M. 2004. Porównanie $w$ Polsce $i$ w krajach UE, Rynek Budowlany, Nr 379, 3.

15. Ubreziova I, Horska E. (EDS.) 2013. Modern Management in the $21^{\text {st }}$ Century, GARMOND Nitra, Nitra.

16. WIŚNIEWSKA K. 2005. Niemiecki rynek budowlany najbardziej atrakcyjny $w$ Europie, Rynek Budowlany, 8 (nr 396).

17. Witakowski P., Grauman R., Bernasik J., Mikrut S., Kwiatkowski W., Mazurek G., KozArzewsKi M., UHL T., HANC A. 2010. System Kompleksowego Zarzadzania Jakościa w Budownictwie. Bezprzewodowy monitoring, obiektów budowlanych, Instytut Techniki Budowlanej, Warszawa.

18. http://cerbud.org.pl dostęp 3.03.2016.

19. http://gwarantowanystyropian.pl/wp-content/uploads/2015/05/LISTA-20141.pdf dostęp 3.03.2016. 